\title{
XYLITOL PRODUCTION FROM WHEAT STRAW HEMICELLULOSIC HYDROLYSATE: HYDROLYSATE DETOXIFICATION AND CARBON SOURCE USED FOR INOCULUM PREPARATION
}

\author{
Larissa Canilha*; Walter Carvalho; Maria das Graças Almeida Felipe; João Batista de Almeida e Silva \\ Universidade de São Paulo, Escola de Engenharia de Lorena, Departamento de Biotecnologia, Lorena, SP, Brasil
}

Submitted: April 23, 2007; Returned to authors for corrections: December 08, 2007; Approved: February 19, 2008.

\begin{abstract}
Wheat straw hemicellulosic hydrolysate was used for xylitol bioproduction. The use of a xylose-containing medium to grow the inoculum did not favor the production of xylitol in the hydrolysate, which was submitted to a previous detoxification treatment with $2.5 \%$ activated charcoal for optimized removal of inhibitory compounds.
\end{abstract}

Key-words: Wheat straw hemicellulosic hydrolysate; Hydrolysate detoxification; Inoculum preparation; Candida guilliermondii; Xylitol production.

Xylitol is a sweetener with outstanding anticariogenic properties. It is suitable for diabetics, prevents osteoporosis, can replace antibiotics in the treatment of otitis and is capable of intervening in the initial steps of infections in patients with cystic fibrosis (7). Its production by biotechnological means is expected to be cheaper than the traditional chemical process because it does not requires pure xylose and is carried out under mild temperature and pressure conditions (7).

In the present study, the carbon source present in the medium used to grow the cells during the preparation of the inoculum was either glucose or a mixture of glucose and xylose. This last sugar was added to the medium used to grow the inoculum in order to induce the expression of enzymes necessary for xylose metabolism, like xylose reductase and xylitol dehydrogenase (16). It was expected that the growth of the cells in an inducing medium would speed up the xylitol bioproduction in the hydrolysate-based medium, since the xylose-to-xylitol bioconversion is influenced by the type and ratio of sugars present in fermentation media (18).

The presence of inhibitory compounds in the hemicellulosic hydrolysate, originated during the hydrolysis of the raw material, negatively influences the xylose-to-xylitol bioconversion. Therefore, the removal of inhibitors (organic acids, sugar degradation compounds and lignin derivatives) from the hydrolysates prior to the fermentation generally leads to improved bioconversion rates and yields (7). A number of methods can be used for hydrolysate detoxification, including $\mathrm{pH}$ adjustment (10), adsorption into ion exchange resins (17) and adsorption into active charcoal, which presents a high efficiency associated to a low-cost (11). In the present study, two levels of active charcoal were tested to detoxify the wheat straw hydrolysate prior to xylitol bioproduction. It was expected that a higher amount of active charcoal (adsorbing matrix) would favor the xylitol bioproduction due to a higher elimination of undesirable inhibiting compounds.

The materials and methods were as follows: The wheat straw was hydrolyzed with dilute sulfuric acid (4) and concentrated threefold at $70^{\circ} \mathrm{C}$ under vacuum. The $\mathrm{pH}$ of the concentrated hydrolysate was then raised to 7.0 with $\mathrm{CaO}$ and reduced to 5.5 with $\mathrm{H}_{3} \mathrm{PO}_{4}$ (1). The hydrolysate thus obtained was submitted to adsorption into active charcoal at $200 \mathrm{rpm}$ and $30^{\circ} \mathrm{C}$ for $1 \mathrm{~h}$. The ratio between active charcoal mass and hydrolysate volume was $1: 10\left(10 \%\right.$ active charcoal adsorption $\left.-H D_{l}\right)$ or $1: 40(2.5 \%$ active charcoal adsorption - $H D_{2}$ ). After removal of the precipitate by vacuum filtration, the hydrolysates were sterilized at $111^{\circ} \mathrm{C}$ for $15 \mathrm{~min}$. The yeast Candida guilliermondii FTI

*Corresponding Author. Mailing address: Universidade de São Paulo, Escola de Engenharia de Lorena, Departamento de Biotecnologia, CP 116, CEP 12602-810, Lorena, São Paulo, Brasil. Tel.: +55 (12) 3159-5107. E-mail: larissa@debiq.eel.usp.br 
20037 (2) was used to promote the xylose-to-xylitol bioconversions. A loopful of cells was transferred to $125-\mathrm{mL}$ Erlenmeyer flasks containing $50 \mathrm{~mL}$ of medium consisting of $(\mathrm{g} /$ L) 2.0 ammonium sulfate, 0.1 calcium chloride and 20.0 rice bran. Either one or two carbon sources were used to grow the cells, namely 30.0 xylose and 7.0 glucose $\left(I P_{1}\right)$ or 37.0 glucose $\left(I P_{2}\right)$. The cells were then incubated at $30^{\circ} \mathrm{C}$ and $200 \mathrm{rpm}$ for $24 \mathrm{~h}$, collected by a 15 -min centrifugation at $2000 \mathrm{~g}$ and re-suspended in sterile distilled water. The fermentations (triplicates) were carried out in $125-\mathrm{mL}$ Erlenmeyer flasks containing $50 \mathrm{~mL}$ of medium and $0.5 \mathrm{~g} / \mathrm{L}$ initial cell concentration, at $30^{\circ} \mathrm{C}$ and 200 rpm for $72 \mathrm{~h}$. The medium was composed by the detoxified hydrolysates supplemented with $(\mathrm{g} / \mathrm{L}) 1.0$ ammonium sulfate and 5.0 rice bran extract, and had its $\mathrm{pH}$ adjusted to 6.0 prior to inoculation (4). Sugars, xylitol, acetic acid, furfural and hydroxymethylfurfural (HMF) concentrations were determined by HPLC (17). Lignin derivatives were determined by UV spectroscopy (4). Cell concentrations were determined by VIS spectroscopy and correlated with the cell dry-weight (4).

Fig. 1-A shows the profiles of sugars and acetic acid consumptions, of xylitol production and of cell growth during the bioconversion carried out with cells grown in a medium elaborated with xylose + glucose $\left(I P_{1}\right)$ and hydrolysate detoxified with $10 \%$ active charcoal $\left(H D_{l}\right)$. As can be seen, glucose was rapidly consumed within the first $24 \mathrm{~h}$ of fermentation. At the same period, the yeast consumed $31 \%$ of the available xylose, thus indicating that a simultaneous consumption of xylose and glucose may have occurred in the assay. Such a simultaneous consumption of xylose and glucose was also previously observed by Silva and Felipe (16). Arabinose and acetic acid were also assimilated by the yeast during the fermentation. It is known that the presence of arabinose induces the enzyme xylose reductase and stimulates the yield and productivity of the xylose-to-xylitol bioconversion (18). A low consumption of acetic acid has previously been reported to improve the microbial growth (5). In the present study, a high cell concentration $(7.2 \mathrm{~g} /$ L) was observed at the end of the assay. During the first $24 \mathrm{~h}$, the cells exhibited a pronounced growth, possibly due to the availability of the six-carbon sugar glucose. Afterwards, between 24 and $48 \mathrm{~h}$, a "stationary" phase with no cellular growth and pronounced xylitol production was observed. By the end of the fermentation, a xylitol production of $24.2 \mathrm{~g} / \mathrm{L}$ was observed, resulting in a productivity of $0.34 \mathrm{~g} / \mathrm{L} \mathrm{h}$ and in a bioconversion yield of $0.48 \mathrm{~g} / \mathrm{g}$ (efficiency of $52.3 \%$ ).

The presence of glucose in the fermentation medium can influence the xylose-to-xylitol bioconversion. For instance, when cultivated in a wood hemicellulosic hydrolysate, the yeast Candida parapsilosis exhibited a faster and more efficient bioconversion in the presence of glucose (glucose:xylose ratio of 1:2.5) than in the absence of this sugar (14). In other example (8), a two-substrate fermentation optimized for xylitol production with the yeast Candida tropicalis $(32 \mathrm{~g} / \mathrm{L}$ glucose and $100 \mathrm{~g} / \mathrm{L}$
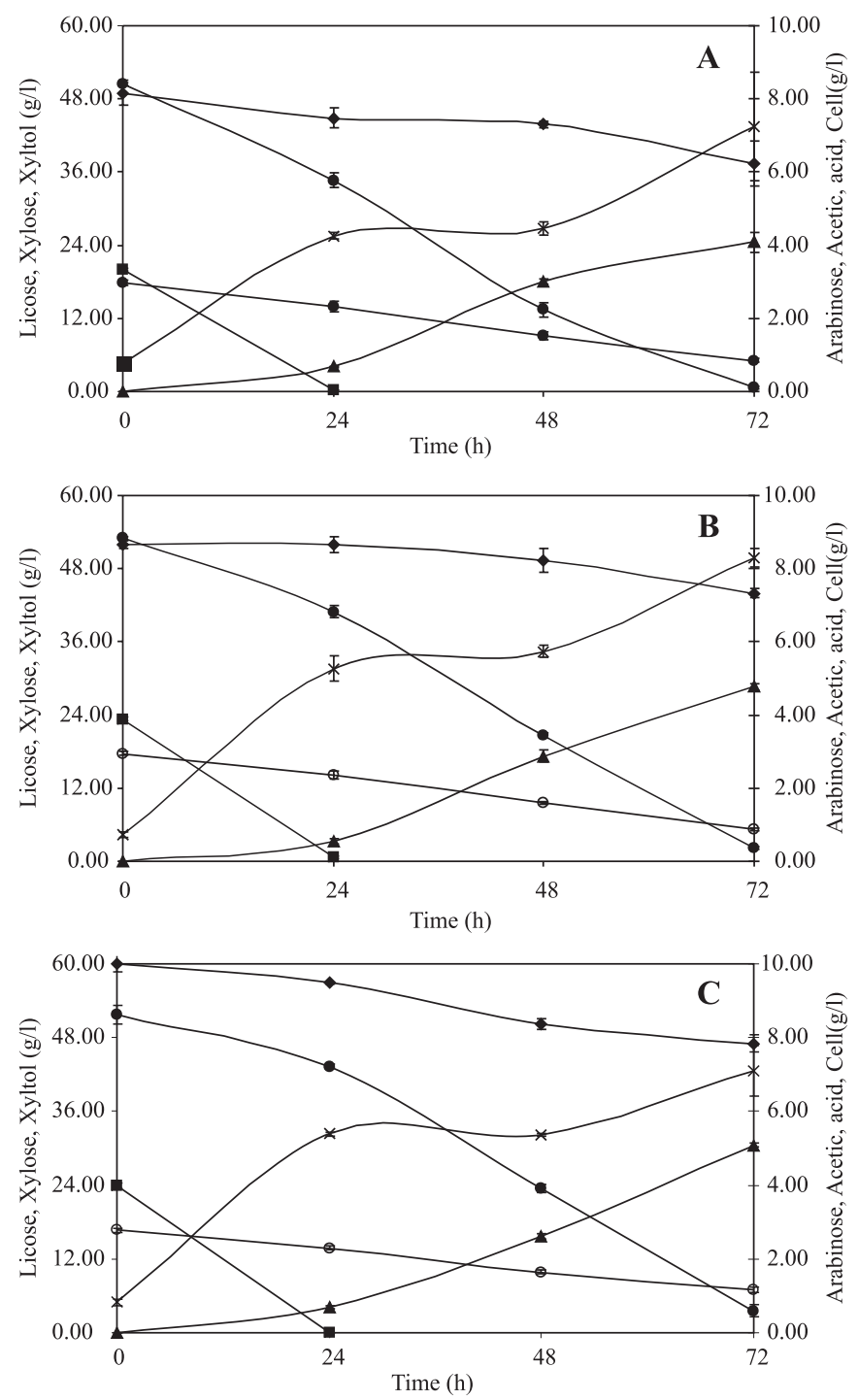

Figure 1 Profiles of glucose (closed square), xylose (closed circle), arabinose (closed lozenge) and acetic acid (open circle) consumptions as well as of xylitol production (closed triangle) and of cell growth (X). Assays: A) $H D_{1}+I P_{1}$; B) $H D_{2}+I P_{1}$; C) $H D_{2}+I P_{2}$. Average values of triplicates with standard deviations (error bars).

xylose) led to a bioconversion yield of $0.81 \mathrm{~g} / \mathrm{g}$ and to a productivity of $5.06 \mathrm{~g} / \mathrm{L} \mathrm{h}$. Such values were 1.4 and 1.85 times higher, respectively, than those obtained in the absence of glucose. For the yeast Candida guilliermondii FTI 20037, a ratio between glucose and xylose of 1:5 was previously demonstrated to improve the bioconversion yield $(0.59 \mathrm{~g} / \mathrm{g})$ and productivity $(0.53 \mathrm{~g} / \mathrm{L} \mathrm{h})$ in a sugarcane bagasse-based fermentation medium (16). For the yeast $C$. tropicalis, glucose concentrations of up to $20 \mathrm{~g} / \mathrm{L}$ did not hinder the bioconversion 
in a xylose-based medium (18). In the present study, the glucose:xylose ratio was 1:2.8 and resulted in bioconversion yield of $0.48 \mathrm{~g} / \mathrm{g}$ and productivity of $0.34 \mathrm{~g} / \mathrm{L} \mathrm{h}$.

As can be seen in Fig. 1-B, the use of a lower amount of active charcoal $(2.5 \%)$ to detoxify the hydrolysate resulted in profiles of xylose consumption, xylitol production and cell growth similar to those observed when the hydrolysate was detoxified with $10 \%$ active charcoal (Fig. 1-A). In fact, the bioconversion parameters were slightly increased (production of $28.6 \mathrm{~g} / \mathrm{L}$, productivity of $0.40 \mathrm{~g} / \mathrm{L} \mathrm{h}$ and yield of $0.54 \mathrm{~g} / \mathrm{g}$ ), suggesting that only $2.5 \%$ active charcoal is sufficient to promote a good detoxification of the wheat straw hydrolysate prior to fermentation. A similar behavior was also observed in rice straw hydrolysate, when the best xylose-to-xylitol bioconversion yield $(0.72 \mathrm{~g} / \mathrm{g})$ and productivity $(0.61 \mathrm{~g} / \mathrm{L} \mathrm{h})$ were achieved by promoting the detoxification with only $2.5 \%$ active charcoal (11).

Fig. 1-C shows the profiles of sugars and acetic acid consumption, xylitol production and cell growth during the bioconversion whose inoculum was grown in a medium with glucose $(37 \mathrm{~g} / \mathrm{L})$ as the sole carbon source. In this experiment, only $2.5 \%$ active charcoal was used to detoxify the hydrolysate. In this assay, the bioconversion parameters were slightly better than those observed when both glucose $(7 \mathrm{~g} / \mathrm{L})$ and xylose (30 $\mathrm{g} / \mathrm{L}$ ) were used as carbon sources in the medium used to grow the inoculum (Figure 1-B). A xylitol production of $30.5 \mathrm{~g} / \mathrm{L}$ was achieved after $72 \mathrm{~h}$ of fermentation, resulting in productivity of $0.42 \mathrm{~g} / \mathrm{L} \mathrm{h}$ and bioconversion yield of $0.59 \mathrm{~g} / \mathrm{g}$. Such findings suggest that the cheaper sugar glucose can be used as the sole carbon source to grow the C. guilliermondii FTI 20037 cells for a subsequent xylose-to-xylitol bioconversion in wheat straw hemicellulosic hydrolysate. Moreover, they confirm the validity of using glucose as the sole carbon source for inoculum preparation in experiments aimed at xylitol bioproduction $(9,12$ 13,15).

As can be seen in Table 1, the best results achieved in the present study (xylitol production of $30.5 \mathrm{~g} / \mathrm{L}$, productivity of $0.42 \mathrm{~g} / \mathrm{L} \mathrm{h}$ and yield of $0.59 \mathrm{~g} / \mathrm{g}$ ) were lower than those obtained in sugarcane bagasse (1) and rice straw (11) hydrolysates. At the same time, they were higher than those observed in eucalyptus hydrolysates $(3,17)$ and in an immobilized cell system (6). It is difficult to compare the results obtained by different researchers since many variables influence the xylose-to-xylitol bioconversion in hemicellulosic hydrolysates. In spite of this, the interesting parameters of bioconversion attained in the rice straw hydrolysate may certainly be related with the high xylose concentration used in the experiment. While a considerably high bioconversion yield could be achieved in the sugarcane bagasse hydrolysate using a relatively low initial cell concentration $(0.5 \mathrm{~g} / \mathrm{L})$, the poor bioconversions observed in the eucalyptus hydrolysate were attributed to a very high concentration of inhibiting hydrolysis by-products.

As a whole, the present study points to the fact that the wheat straw is a potential raw material to be used as a source of xylose for xylitol bioproduction. The toxic compounds present in the hydrolysate can be efficiently removed by a simple detoxification strategy based on $\mathrm{pH}$ alteration and active charcoal adsorption. Moreover, glucose can be used as the sole carbon source to grow the inoculum of $C$. guilliermondii FTI 20037 cells in order to provide good xylose-to-xylitol bioconversion rates and yields in the detoxified hydrolysate.

Table 1. Data regarding xylitol bioproduction with the yeast C. guilliermondii FTI 20037 in hydrolysates from different raw materials.

\begin{tabular}{|c|c|c|c|c|c|c|c|c|}
\hline Raw material & MD & $\mathrm{CS}$ & $\mathrm{X}_{\mathrm{o}}(\mathrm{g} / \mathrm{L})$ & $\mathrm{S}_{\mathrm{o}}(\mathrm{g} / \mathrm{L})$ & $P(g / L)$ & $\mathrm{Q}_{\mathrm{P}}(\mathrm{g} / \mathrm{L} \mathrm{h})$ & $Y_{P / S}(g / g)$ & Reference \\
\hline $\begin{array}{l}\text { Wheat } \\
\text { straw }\end{array}$ & $\begin{array}{c}\mathrm{pH} \text { alteration with } \\
2.5 \% \text { active charcoal }\end{array}$ & Glucose $(37.0 \mathrm{~g} / \mathrm{L})$ & 0.5 & 51,7 & 30.5 & 0.42 & 0.59 & this work \\
\hline $\begin{array}{l}\text { Sugarcane } \\
\text { bagasse }\end{array}$ & $\begin{array}{c}\mathrm{pH} \text { alteration with } \\
2.4 \% \text { active charcoal }\end{array}$ & Xylose $(30.0 \mathrm{~g} / \mathrm{L})$ & 0.5 & - & 29.6 & 0.47 & 0.79 & (1) \\
\hline $\begin{array}{l}\text { Sugarcane } \\
\text { bagasse }\end{array}$ & $\begin{array}{c}\mathrm{pH} \text { alteration with } \\
2.4 \% \text { active charcoal }\end{array}$ & Xylose (30.0 g/L) & $1.6^{*}$ & 43.4 & 21.0 & 0.44 & 0.54 & (6) \\
\hline $\begin{array}{l}\text { Eucalyptus } \\
\text { wood }\end{array}$ & $\begin{array}{c}\mathrm{pH} \text { alteration with } \\
10.0 \% \text { active charcoal }\end{array}$ & $\begin{array}{l}\text { Xylose }(30.0 \mathrm{~g} / \mathrm{L}) \text { and } \\
\text { Glucose }(7.0 \mathrm{~g} / \mathrm{L})\end{array}$ & 3.0 & 60.0 & 10.0 & 0.10 & 0.20 & (3) \\
\hline $\begin{array}{l}\text { Eucalyptus } \\
\text { wood }\end{array}$ & $\begin{array}{c}\mathrm{pH} \text { alteration with } \\
5.0 \% \text { active charcoal }\end{array}$ & $\begin{array}{l}\text { Xylose }(30.0 \mathrm{~g} / \mathrm{L}) \text { and } \\
\text { Glucose }(2.0 \mathrm{~g} / \mathrm{L})\end{array}$ & 3.0 & 56.5 & 11.1 & 0.09 & 0.26 & (17) \\
\hline Rice straw & $\begin{array}{c}\mathrm{pH} \text { alteration with } \\
2.5 \% \text { active charcoal }\end{array}$ & Xylose $(20.0 \mathrm{~g} / \mathrm{L})$ & 3.0 & 90.0 & 59.0 & 0.61 & 0.72 & (11) \\
\hline
\end{tabular}

MD: Method used for hydrolysate detoxification; CS: Carbon source used for inoculum preparation; $\mathrm{X}_{\mathrm{o}}$ : Initial cell concentration; $\mathrm{S}_{\mathrm{o}}$ : Initial xylose concentration; P: Xylitol production; $\mathrm{Q}_{\mathrm{P}}$ : Xylitol productivity; $\mathrm{Y}_{\mathrm{P} / \mathrm{s}}$ : Xylose-to-xylitol conversion yield; -: data not presented. 


\section{ACKNOWLEDGEMENTS}

The authors gratefully acknowledge the financial support of Fapesp and CNPq and thank Ms. L.C.M. Robin for revising this manuscript.

\section{RESUMO}

\section{Produção de xilitol em hidrolisado hemicelulósico de palha de trigo: destoxificação do hidrolisado e fonte de carbono utilizada para o preparo do inóculo}

Hidrolisado hemicelulósico de palha de trigo foi utilizado para a bioprodução de xilitol. O uso de meio contendo xilose para crescer o inóculo não favoreceu a produção de xilitol no hidrolisado, que foi submetido a um tratamento prévio de destoxificação com $2.5 \%$ de carvão ativo para remoção otimizada de compostos inibitórios.

Palavras-chave: Hidrolisado hemicelulósico de palha de trigo; Destoxificação do hidrolisado; Preparo do inóculo; Candida guilliermondii; Produção de xilitol.

\section{REFERENCES}

1. Alves, L.A.; Felipe, M.G.A.; Almeida e Silva, J.B.; Silva, S.S.; Prata, A.M.R. (1998). Pretreatment of sugarcane bagasse hemicellulose hydrolysate for xylitol production by Candida guilliermondii. Appl. Biochem. Biotechnol., 70/72, 89-98.

2. Barbosa, M.F.S.; Medeiros, M.B.; Mancilha, I.M.; Schneider, H.; Lee H. (1998). Screening of yeasts for production of xylitol from Dxylose and some factors which affect xylitol yield in Candida guilliermondii. J. Ind. Microbiol., 3, 241-51.

3. Canettieri, E.V.; Almeida E Silva, J.B.; Felipe, M.G.A. (2001). Application of factorial design to the study of xylitol production from eucalyptus hemicellulosic hydrolysate. Appl. Biochem. Biotechnol., 24, 159-168.

4. Canilha, L.; Carvalho, W.; Almeida e Silva, J.B. (2005). Influence of medium composition on xylitol bioproduction from wheat straw hemicellulosic hydrolysate. World J. Microbiol. Biotechnol., 21, 10871093.
5. Carvalheiro, F.; Duarte, L.C.; Lopes, S.; Parajó, J.C.; Pereira H.; Gírio, F.M. (2005). Evaluation of the detoxification of brewery's spent grain hydrolysate for xylitol production by Debaryomyces hansenii CCMI 941. Process Biochem., 40, 1215-1223.

6. Carvalho, W.; Silva, S.S.; Santos, J.C.; Converti, A. (2003). Xylitol production by Ca-alginate entrapped cells: comparison of different fermentation system. Enzyme Microb. Technol., 32, 553-559.

7. Felipe, M.G.A. (2004). Biotechnological production of xylitol from lignocellulosic materials. In: Saha, B.C.; Hayashi, K. (ADC Symposium series 889). Lignocellulose Biodegradation. American Chemical Society, Washington, USA, p.300.

8. Kim, J.H.; Ryu, Y.W.; Seo, J.H. (1999). Analysis and optimization of two-substrate fermentation for xylitol production using Candida tropicalis. J. Ind. Microbiol. Biotechnol., 22, 181-186.

9. Kwon, S.G.; Park, S.W.; Oh, D.K. (2006). Increase of xylitol productivity by cell-recycle fermentation of Candida tropicalis using submerged membrane bioreactor. J. Biosci. Bioeng., 101, 13.

10. Martinez, A.; Rodriguez, M.E.; Wells, M.L.; York, S.W.; Preston, J.F.; Ingram, L.O. (2001). Detoxification of Dilute Acid Hydrolysates of Lignocellulose with Lime. Biotechnol. Progr., 17, 287-293.

11. Mussatto, S.I.; Roberto, I.C. (2001). Hydrolysate detoxification with activated charcoal for xylitol production by Candida guilliermondii. Biotechnol. Lett., 23, 1681-1684.

12. Oh, D.K.; Kim, S.Y. (1998). Increase of xylitol yield by feeding xylose and glucose in Candida tropicalis. Appl. Biochem. Biotechnol., 50, 419-425.

13. Pfeifer, M.J.; Silva, S.S.; Felipe, M.G.A.; Roberto, I.C.; Mancilha, I.M. (1996). Effect of culture conditions on xylitol production by Candida guilliermondii FTI20037. Appl. Biochem. Biotechnol., 57/58, 423-430.

14. Preziosi-Belloy, L.; Nolleau, V.; Navarro, J.M. (1997). Fermentation of hemicellulosic sugars and sugars mixtures to xylitol by Candida parapsilosis. Enzyme Microb. Technol., 21, 24-129.

15. Silva, D.D.V.; Felipe, M.G.A.; Mancilha, I.M.; Silva, S.S. (2005). Evaluation of inoculum of Candida guilliermondii grown in presence of glucose on xylose reductase and xylitol production during batch fermentation of sugarcane bagasse hydrolysate. Appl. Biochem. Biotechnol., 121-124, 427-437.

16. Silva, D.D.V.; Felipe, M.G.A. (2006). Effect of glucose:xylose ratio on xylose reductase and xylitol dehydrogenase activities from Candida guilliermondii in sugarcane bagasse hydrolysate. J. Chem. Technol. Biotechnol., 81, 1294-1300.

17. Villarreal, M.L.M.; Prata, A.M.R.; Felipe, M.G.A.; Almeida e Silva, J.B. (2006). Detoxification procedures of eucalyptus hemicellulose hydrolysate for xylitol production by Candida guilliermondii. Enzyme Microb. Technol., 40, 17-24.

18. Walther, T.; Hensirisak, P.; Agblevor, F.A. (2001). The influence of aeration and hemicellulosic sugars on xylitol production by Candida tropicalis. Bioresour. Technol., 76, 213-220. 